\title{
An Essay in Praise of Scholastic Theology
}

\author{
Austin Holmes \\ Boston College School of Theology and Ministry (Brighton, MA)
}

\begin{abstract}
This essay attempts to give the Scholastic Theology of the High Middle Ages due praise by inhabiting its beautiful intellectual architecture. Among the core features observed are Scholasticism's methodological vitality explained as an exegetical-humility with patristic roots, the animating principle of desire for union with God, and a conception of Christian doctrine as fundamental to the divine work of human salvation. Rather than engage directly with Scholasticism's fashionable modern enemies, the essay proceeds in successive steps as a lectio magistrorum ("reading of the masters"). Anslem of Canterbury, Hugh of St. Victor, Peter Abelard, Bonaventure, and Thomas Aquinas represent the primary sources of interest. The goal is simply to generate reconsideration of medieval theology through an introduction to atypically studied aspects of a few figures.
\end{abstract}

\section{Text}

A few introductory remarks are in order. An essay in praise of Scholastic theology is one thing; an essay in defense of Scholastic theology is quite another. Moreover, any attempt to limit the value of Scholastic theology to its achievements in contradistinction to, say, liberation or feminist theology would crumble from the category of praise into the less savory territory of a derivative exercise in compare and contrast. Since the siege of Scholasticism enjoys such popularity, its admirers are prone to weaponize its corpus as a countermeasure. There is an occasion for this, though undoubtedly such efforts miss the heart of Scholasticism as a consequence of allowing modernity to command the investigation. My aim is otherwise. If the encounter with Scholastic theology is similar to an object of our experience, it is neither the sword nor the shield. Scholastic theology is the stained-glass window, one particularly extraordinary window in a grand Gothic cathedral — the one that holds my gaze. This is an essay in praise of Scholastic theology, and in so 


\section{HOLMES: IN PRAISE OF SCHOLASTIC THEOLOGY}

few pages our arrested gaze into its resplendent and redounding images will not appreciate every detail, nor perhaps even the most important. Where is the eye to look first?

It seems fitting to dwell on the cathedral. The analogy between the church's most colossal architectural feats and its intellectual traditions brandishes a helpful starting point for this foray into Scholastic theology: specifically the way both relate to time. Namely, for both cathedrals and theological traditions, time is not measured according to hours, weeks, or even years, but according to centuries. In both cases, the constructive task occurs with an eschatological horizon. In the same way that cathedrals are built to last, dogmatic theological construction retains vitality across any historical limit because it aims to speak of the God who remains beyond all limit. It is also for precisely this reason that theology remains wholly fragmentary, tentative, and under construction. Cathedrals are rarely without scaffolding, and would hardly, if ever, attain their grandeur without the patience for restoration and remodeling - an attention to the cracks in the walls, as it were.

All this signifies an important precondition that is fundamental for theological integrity: it is only possible as and when discourse about God declines the attempt to take God's point of view. ${ }^{1}$ Modesty is a virtue, as much for the theologian as anyone else. Here, we might pause a moment in our contemplation of Scholastic theology to hear a detracting voice. "Is it not the case that "the Scholastics' were overly speculative and systematic, guilty of procuring a totalizing rationality, stifling theological creativity, and casting innovation into the outer darkness?" A question is properly given in reply: "Which Scholastics?" To avoid being taken too far afield, this essay presumes a confinement of Scholasticism to the period of the High Middle Ages, reaching from Anselm in the late $11^{\text {th }}$ century until the Reformation. ${ }^{2}$ Suffice it to say (however inadequate) that

\footnotetext{
${ }^{1}$ Rowan Williams, On Christian Theology (Oxford, UK: Blackwell, 2000), 6.

${ }^{2}$ Of course, defining the period of Scholasticism is widely debated. Here I am in agreement with Timothy B. Noone in A Companion to Philosophy in the Middle Ages (Oxford, UK: Blackwell, 2002), 55.
} 


\section{HOLMES: IN PRAISE OF SCHOLASTIC THEOLOGY}

many iterations of 'neo-Scholasticism' are guilty of the aforementioned charges, relying as they did on the same quintessentially modern rationalist presuppositions they hoped to reverse. ${ }^{3}$ One of the more striking differences between Scholasticism and its alleged heir neo-Scholasticism is the latter's monolithic character, very unlike the $11^{\text {th }}-14^{\text {th }}$ centuries. Rather than identifying Scholasticism as a homogenous doctrinal unity, an emerging trend in historical scholarship has been to emphasize a plurality of thought within an underlying identity of method. ${ }^{4}$

Although its method, in all its fullness, would not emerge until the Middle Ages, Scholasticism is detectable in germ among the patristic theologians. ${ }^{5}$ The attempt to reconcile authority and reason—or as Philipp Rosemann has keenly described it in Pauline terms "Christian Folly" and "Greek Wisdom"- accounts for the lion's share of the intellectual toils of medieval Scholastics. ${ }^{6}$ Searching for a similar enterprise in the earlier tradition inevitably runs up against a wall like Tertullian's famous polemic: "What has Athens to do with Jerusalem? What the Academy with the Church?"7 However, it would be overly simplistic to describe the Patristic relationship with philosophy as merely antagonistic. Indeed, the development of creedal faith depended largely on Greek philosophy as an aid in the primary task of biblical exegesis. Perhaps the most important feature Scholastic theology would inherit from its forebears was an indefatigable immersion in scripture. Scholastic theology was, in a word, exegetical—cleaving to the biblical text in such a way that divine revelation was allowed the commanding role. Such a methodological conviction

\footnotetext{
${ }^{3}$ The ressourcement movements, begun in the Nouvelle Theologie in $20^{\text {th }}$ century France with theologians such as Henri de Lubac (carried on by Karl Rahner, Hans Urs von Balthasar, and then especially Bernard Lonergan), furnish this critique.

${ }^{4}$ See especially Philipp Rosemann's chapter "Defining the Scholastic Tradition" in Understanding Scholastic Thought with Foucault (New York, NY: St. Martin's Press, 1999): 45-58.

5 Though he was likely not the first, the $20^{\text {th }}$ century medievalist Martin Grabmann is one of the more well known for this thesis.

${ }^{6}$ Rosemann, Scholastic Thought, 50.

7 Tertullian, Prescription against Heretics, ed. R.F. Refoule, Corpus Christianorum, Series Latina 1.1 (Turnhout: Brepols, 1954), VII.9-12, p.193, 11.32-34. Quoted in Rosemann, Scholastic Thought, 53.
} 


\section{HOLMES: IN PRAISE OF SCHOLASTIC THEOLOGY}

produced readers of the biblical text who were patient and receptive, rather than imposing or suspicious. ${ }^{8}$ This affection for the sacred page, however, did not circumscribe learning from extrabiblical sources. As the Fathers knew well and an abundance of biblical scholarship has since shown, scripture itself makes use of this philosophy—one thinks of the Logos in the prologue to the Gospel of John, or the "suspended from above" perspective on material in the Epistle to the Hebrews. ${ }^{9}$ The medieval Scholastic penchant for the reconciliation of contraries, rooted in an underlying commitment to the unity of all truth, is thus an inheritance from the primitive church.

This dialectical method - in which painstakingly precise argumentation does the heavy lifting in articulating speech about God—can appear offensively tidy, exhibiting an inevitably static and overly intellectual habitus. However, the multiformity of the Scholastic literary corpus which we encounter today tells a different story. Genres abound: disputed questions and summae, trialogues and exegetical commentaries, quodlibets and refutations, translations and hymns. The diversity in modes of theological discourse hailing from the Scholastic period is a testament to the ineffable and inexhaustible object of its theology: the triune God. Even so, one might complain all these university-based texts are isolated from spirituality. On the contrary, the separation of contemplative practice and the Christian life from doctrine is a much later invention. One has only to observe the Scholastics at work. A particularly striking example is Anselm of Canterbury's Proslogion, the source of his famous God is "that than which nothing greater can-be thought" argument for the theological grammar required by ontological perfection. The treatise, mothballed as a philosophical artifact, is a single continuous prayer-a rousing of the mind to the contemplation of God which begins in this way:

\footnotetext{
${ }^{8}$ See David Steinmetz's brilliant essay "The Superiority of Pre-Critical Exegesis" in Theology Today 37, no. 1 (April 1980): 27-38.

${ }^{9}$ Luke Timothy Johnson, "Sacramentality and Sacraments in Hebrews," in The Oxford Handbook of Sacramental Theology, ed. Hans Boersma and Matthew Levering (Oxford: Oxford University Press, 2015), 115.
} 


\section{HOLMES: IN PRAISE OF SCHOLASTIC THEOLOGY}

Come now, insignificant human, fly for a moment from your affairs, escape for a little while from the tumult of your thoughts. Put aside now your weighty cares and leave your wearisome toils. Abandon yourself for a little to God, and rest for a little in Him...Speak now my whole heart, speak now to God: 'I seek your countenance, O Lord. (Ps 26:8)' Come, Lord my God, teach my heart where and how to seek You, where and how to find You...You have created me and re-created me and You have given me all the good things I possess, and still I do not know You...I was made in order to see You, and I have not yet accomplished what I was made for. ${ }^{10}$

St. Anselm will go on to marshal one of the more difficult philosophical arguments of the High Medieval period — but each logical step is coextensive with the soul's movement toward God, a form of ascetical argumentation blazoned in an unparalleled way by St. Bonaventure, the great $13^{\text {th }}$ century Franciscan master of theology, in his Itinerarium.

The genius to this approach lies in the recognition that ordo disciplinae is such that Scholasticism's speculative theology both presumes the spiritual and aims for the doxological. St. Augustine's influence permeates the whole of Scholasticism, but especially the Scholastic thinking around what precedes the task of theology: "It is a very rare thing for a man, after he has contemplated the whole of creation...to pass beyond it, and, by the continued soaring of his mind, to attain to the unchangeable substance of God." ${ }^{11}$ Any method of theological writing which ignores the prelude of regeneration, of healing and illumination, fails to be Scholastic. Moreover, illusions of stale drudgery are dispelled by the strong featuring of desire in Anselm's treatise: "Let me seek You in desiring You; let me desire You in seeking You; let me find You in loving You; let me love You in finding You." 12 What could the unquenchable Scholastic pursuit of understanding be, if not desire? This desire, it must be added, is itself divinely-given. As John Webster writes,

${ }^{10}$ Anselm, Proslogion, in Anselm of Canterbury: The Major Works, ed. Brian Davies and Gillian Evans (Oxford: Oxford University Press, 1998), 84-85.

${ }^{11}$ Augustine, City of God, XI.2, trans. Marcus Dods (New York: Modern Library, 2000), 347.

${ }^{12}$ Anselm, Proslogion, 86-87. 


\section{HOLMES: IN PRAISE OF SCHOLASTIC THEOLOGY}

"theological science is a graced enterprise: not perfected, but mortified and vivified, caught up in the Spirit's work of sanctification."13

Scholastic desire inspired another methodological feature: confidence. The later neo-Scholastic attempt to "totalize" is mostly foreign to the theology of the High Middle Ages. However, faith seeking understanding (fides quarens intellectum) was possessed of a daring disposition, a willingness to take theological risks through innovation. Peter Abelard is an exemplar of Scholastic ingenuity. His wading into the $12^{\text {th }}$ century trinitarian debates would prove crucial in the history of theology. ${ }^{14}$ The master at Notre Dame was among the first (along with Hugh of St. Victor) to develop a systematic account of "attribution," a model of Trinitarian theology where particular divine attributes are associated with one of the three persons: Power (potentia) to the Father, Wisdom (sapientia) to the Son, and Goodness (benignitas) to the Spirit. His method would later be deemed untenable. ${ }^{15}$ Even so, his use of logic in application to the Trinity would compel decades of Scholastic debate over essential attributes and properties of divine persons, the concept of 'number' in reference to God, and what natural reason can grasp of the divine reality.

So far, these introductory remarks have attempted to identify some rarely recognized characteristics of Scholastic theology: its methodological vitality explained as an exegetical-humility with patristic roots, and the central place of desire along with the intellectual risk-taking it engenders. Earlier, I alluded to thinking about Scholastic theology as a stained glass window in a beautiful cathedral. We have only been able to take in a few of its many brilliant panels, often missed despite being at the center. By way of a concluding observation our gaze turns to one final image-

${ }^{13}$ John Webster, God Without Measure (London: Bloomsbury, 2016), 10.

${ }^{14}$ Gilles Emery, Trinity in Aquinas (Ann Arbor, MI: Sapientia Press, 2003), 4-8.

${ }^{15}$ This is because Abelard had not been as diligent to caution against the exclusive attribution of any attribute to a particular person - i.e. we cannot say "power of divinity belongs only to the Father" (which would seem to introduce a division of attributes running contrary to divine simplicity). 


\section{HOLMES: IN PRAISE OF SCHOLASTIC THEOLOGY}

who else, but the Angelic Doctor? Thomas Aquinas has left behind one of the most influential bodies of writing in the course of the church's history, and indeed the history of Western civilization. Leo XIII's encyclical Aeterni Patris spurred a new devotion to the Thomistic corpus which (ironically and not very Thomas-like) has sometimes contributed to a one-dimensional reading of medieval thought to the neglect of many other Scholastic thinkers. ${ }^{16}$ Recent history has also witnessed particular threads of Thomism which instrumentalize the saint's $2 u v r e$ for distinctly modern causes. Thomas, nevertheless, remains a magnificent conversation partner.

The first question of the first part of Thomas's Summa theologiae asks about the nature and extent of sacra doctrina. Besides philosophy, what other teaching could be required? Aristotle's Metaphysics treats even of God, so what could remain unknown? Thomas answers that "it was necessary for the salvation of humankind that there should be a knowledge revealed by God besides philosophical science built up by human reason." 17 Theology, as a constructive human task, is caught up with the divine work of human salvation. Aquinas will go on to explain that the chief aim of sacred doctrine is to teach the knowledge of God, which he structures as: 1) the intratrinitarian life, and the procession of all creatures from God, 2) humankind's advance toward God through a life of virtue and indwelt by the Spirit, and 3) Christ, who as man, is our way to God. Thomas's beginning with the perfection and fullness of God's life in himself can alert us to what otherwise remains second-nature in our contemporary methodological preference for God's life ad extra. Further, precisely as ordered to salvation, Thomas's theology bears an undeniable Christo-logic: salvation is our being taught the truth about God by God himself who became

\footnotetext{
${ }^{16}$ Rosemann, Scholastic Thought, 3.

17 Thomas Aquinas, Summa Theologiae, I, q. 1, a. .1, in vol. 13, trans. Laurence Shapcote (Lander, WY: The Aquinas Institute for the Study of Sacred Doctrine, 2012).
} 


\section{HOLMES: IN PRAISE OF SCHOLASTIC THEOLOGY}

incarnate, taking on flesh in order to take on disciples - the inauguration of a restorative process of learning. ${ }^{18}$

The question posed to theology and ministry today is not whether we have much to learn from the Scholastics by indwelling their intellectual architecture-we do-but will we learn? How primary is exegesis, and how do we encounter the biblical text? Does desire drive our syllogisms? Is doctrine still considered consequential for the building up of a redeemed people? Do we think that knowledge of God is eternal life? Now that introductory remarks are concluded, we might move on to a closer examination of Anselm's essay On Behalf of the Fool, or Peter Lombard's Sentences which were the most scrutinized and important text of the Middle Ages surpassed only by Scripture itself, or Richard of St. Victor's argument in his De Trinitate for the necessary plurality of persons given divine perfection. Or, we might step back a few paces to take in Scholastic theology as a whole, allowing its images to dazzle our eyes, letting its precise and carefully conceived beauty lead us anew into astonishment, teaching our souls to hunger and our lips to praise.

${ }^{18}$ ST III, q. 42, a. 4. 


\section{HOLMES: IN PRAISE OF SCHOLASTIC THEOLOGY}

\section{Bibliography}

Anselm. Proslogion. In Anselm of Canterbury: The Major Works. Edited by Brian Davies and Gillian Evans. Oxford: Oxford University Press, 1998.

Augustine. City of God. Translated by Marcus Dods. New York: Modern Library, 2000.

Emery, Gilles. Trinity in Aquinas. Ann Arbor, MI: Sapientia Press, 2003.

Johnson, Luke Timothy. "Sacramentality and Sacraments in Hebrews." In The Oxford Handbook of Sacramental Theology, edited by. Hans Boersma and Matthew Levering, 109-122. Oxford: Oxford University Press, 2015.

Noone, Timothy B. A Companion to Philosophy in the Middle Ages. Oxford: Blackwell, 2002.

Rosemann, Philipp. Understanding Scholastic Thought with Foucault. New York: St. Martin's Press, 1999.

Steinmetz, David. "The Superiority of Pre-Critical Exegesis." Theology Today 37, no. 1 (April 1980): 27-38.

Tertullian, Prescription against Heretics. Edited by R.F. Refoule. Corpus Christianorum, Series Latina 1.1. Turnhout: Brepols, 1954.

Thomas Aquinas. Summa theologiae. Translated by Laurence Shapcote. Edited by Enrique Alarcón and John Mortensen. Lander, WY: The Aquinas Institute for the Study of Sacred Doctrine, 2012.

Webster, John. God Without Measure. London: Bloomsbury, 2016.

Williams, Rowan. On Christian Theology. Oxford: Blackwell, 2000. 